\title{
FEAR OF BREAKDOWN
}




\title{
NEW DIRECTIONS IN CRITICAL THEORY
}

\author{
AMY ALLEN, GENERAL EDITOR
}

New Directions in Critical Theory presents outstanding classic and contemporary texts in the tradition of critical social theory, broadly construed. The series aims to renew and advance the program of critical social theory, with a particular focus on theorizing contemporary struggles around gender, race, sexuality, class, and globalization and their complex interconnections.

For a complete list of books in the series, see pages $293^{-95}$. 


\section{FEAR OF \\ BREAKDOWN}

POLITICS AND

PSYCHOANALYSIS

NOËLLE MCAFEE

Columbia University Press New York 


\section{$\$$ \\ Columbia University Press \\ Publishers Since 1893}

New York Chichester, West Sussex

cup.columbia.edu

Copyright (C) 2019 Columbia University Press

All rights reserved

Library of Congress Cataloging-in-Publication Data

Names: McAfee, Noelle, i96o- author.

Title: Fear of breakdown : politics and psychoanalysis / Noelle McAfee.

Description: New York: Columbia University Press, 2019. | Series: New directions in critical theory | Includes bibliographical references and index. Identifiers: LCCN 2018047977 | ISBN 978023II92682 (cloth : alk. paper) | ISBN 9780231192699 (pbk. : alk. paper) | ISBN 97802315499 I2 (e-book)

Subjects: LCSH: Democracy-Psychological aspects. | Deliberative democracy. |

Psychoanalysis-Political aspects. | Political psychology. | Critical theory.

Classification: LCC JC423.Mi265 2019 | DDC 320.0I-dc23

$\mathrm{LC}$ record available at https://lccn.loc.gov/2018047977

Columbia University Press books are printed on permanent and durable acid-free paper.

Printed in the United States of America

Cover design: Rebecca Lown 
To Guthrie, V, and the future

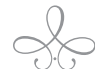


